\title{
Siklus Hidup Spodoptera frugiperda Dengan Pemberian Pakan Kangkung dan Daun Bawang di Laboratorium
}

\section{(Life Cycle of Spodoptera frugiperda with Feeding Kale and Leeks in Laboratory)}

\author{
Ichsan Luqmana Indra Putra*, Nanda Dwi Martina
}

(Diterima September 2020/Disetujui April 2021)

\begin{abstract}
ABSTRAK
Spodoptera frugiperda ditemukan sudah masuk di Indonesia dan merusak tanaman jagung. Adanya perubahan iklim di Indonesia dikhawatirkan membuat hama tersebut dapat bermigrasi ke tanaman lain selain jagung, seperti kangkung dan bawang daun. Penelitian ini dilakukan untuk mengamati siklus hidup $S$. frugiperda dengan perlakuan pakan daun kangkung, daun bawang, dan daun jagung sebagai kontrol. Larva berasal dari ladang jagung yang diserang hama oleh $S$. frugiperda dan dibiakkan di laboratorium. Peubah yang diamati ialah panjang larva, diameter kepala, panjang pupa, jumlah telur, nisbah seks, dan waktu untuk menyelesaikan satu siklusnya. Siklus hidup $S$. frugiperda bervariasi antara 37 dan 47 hari. Pakan daun kangkung merupakan pakan yang baik untuk pertumbuhan S. frugiperda dibandingkan dua pakan lainnya, sedangkan daun jagung baik dalam fekunditas.
\end{abstract}

Kata kunci: fekunditas, jagung, nisbah kelamin, pertumbuhan, siklus hidup

\section{ABSTRACT}

Spodoptera frugiperda was found to have entered Indonesia and damaged maize crops. There is a concern that climate change in Indonesia will cause these pests to migrate to other crops besides corn, such as kale and leeks. This research was conducted to observe the life cycle of $S$. frugiperda with feed treatment of kale leaves, leeks and corn leaves as a control. The larvae came from corn fields that were infested by $S$. frugiperda and were cultured in the laboratory. The variables observed were larva length, head diameter, pupa length, number of eggs, sex ratio, and time to complete one cycle. The life cycle of $S$. frugiperda varies between 37 and 47 days. Kale leaf feed is a good feed for the growth of $S$. frugiperda compared to the other two feeds, while corn leaf is good in fecundity.

Keywords: corn, fecundity, growth, life cycle, sex ratio

\section{PENDAHULUAN}

Spodoptera frugiperda merupakan ngengat asli daerah tropis dari Amerika Serikat hingga Argentina. Awal 2016 hama ini ditemukan untuk pertama kali di Afrika Tengah dan Barat dan pada tahun 2018 dilaporkan sudah menyerang di hampir seluruh negara Sub-Sahara Afrika, kecuali Djibouti, Eritrea, dan Lesotho. Di Indonesia, S. frugiperda telah ditemukan merusak tanaman jagung di Kabupaten Pasaman Barat, Sumatera Barat (Nonci et al. 2019) dan di Bandung, Sumedang, dan Garut, Jawa Barat (Maharani et al. 2019).

Hama S. frugiperda dikhawatirkan dapat menyerang tanaman budi daya lain di Indonesia, salah satunya ialah tanaman sayur seperti kangkung dan bawang daun. Kedua tanaman sayur ini digemari oleh masyarakat di Indonesia. S. litura merupakan hama yang menyerang pada tanaman kangkung (Kianmatee

Program Studi Biologi, Universitas Ahmad Dahlan, Jl. Ahmad Yani (Ringroad Selatan) Tamanan Banguntapan Bantul Yogyakarta 55166

* Penulis Korespondensi:

Email: ichsan.luqmana@bio.uad.ac.id dan Ranamukhhaarachchi 2007; Razak et al. 2014). Demikian juga $S$. exigua merupakan hama tanaman bawang (Moekasan et al. 2013; Kementan 2017; Marsadi et al. 2017). Hama $S$. exigua dikhawatirkan dapat menyerang tanaman kangkung dan bawang daun

Oleh karena itu, penelitian ini bertujuan mengamati siklus hidup $S$. frugiperda dengan pakan daun kangkung dan daun bawang. Hasil penelitian dapat digunakan untuk peramalan serangan $S$. frugiperda pada pertanaman kangkung dan bawang daun.

\section{METODE PENELITIAN}

\section{Alat dan Bahan}

Alat-alat yang digunakan dalam pengambilan $S$. frugiperda di lapang adalah akuarium plastik ukuran $21 \times 12 \times 14 \mathrm{~cm}$, gelas plastik ukuran $400 \mathrm{~mL}$, toples berukuran 5 L. Setelah diambil dari lapang, $S$. frugiperda kemudian dipelihara di laboratorium. Alat yang digunakan dalam pemeliharaan adalah benang jahit, kapas, kain organdi, dan karet gelang. Alat yang digunakan dalam pengambilan data $S$. frugiperda 
adalah timbangan analitik, kuas kecil, nampan, gunting, pisau, kertas label, dan alat tulis.

Bahan yang digunakan dalam pemeliharaan $S$. frugiperda di laboratorium adalah larva $S$. frugiperda, daun jagung sebagai pakan $S$. frugiperda, kangkung, bawang daun, larutan madu, kertas minyak, oli bekas, air keran, dan tisu.

\section{Waktu dan Tempat Penelitian}

Penelitian diawali dengan mencari ulat $S$. frugiperda di ladang jagung daerah Bantul tepatnya di daerah Bangunharjo Kecamatan Sewon dengan titik koordinat $7^{\circ} 50^{\prime} 07.93^{\prime \prime}$ S $110^{\circ} 21^{\prime} 56.33^{\prime \prime}$ E dan Sumber Agung Kecamatan Jetis dengan titik koordinat $7^{\circ} 54^{\prime} 06.23$ " S 110²1'49.14" E pada bulan Oktober-November 2019. Pemeliharaan $S$. frugiperda yang didapatkan dari lapang dilakukan pada bulan November-Desember 2019. Perlakuan pemberian pakan dan pengamatan siklus hidup $S$. frugiperda dilakukan di Laboratorium Botani, Program Studi Biologi, Universitas Ahmad Dahlan pada bulan Desemner 2019-Januari 2020.

\section{Sumber Spodoptera frugiperda}

Larva Spodoptera frugiperda dikoleksi di ladang jagung daerah Bantul, Kecamatan Sewon, Desa Bangunharjo dan Kecamatan Jetis, Desa Sumber Agung. Adanya hama ini dicirikan dari lubang gerekan pada daun jagung dan bekas gerekan larva ditandai serbuk kasar menyerupai serbuk gergaji pada permukaan atas daun dan sekitar pucuk tanaman. Larva diambil dan disimpan di dalam akuarium plastik dengan pakan daun jagung. Larva tersebut dipelihara pada suhu $25-29^{\circ} \mathrm{C}$ di laboratorium yang dijaga kelembapannya $>40 \%$. Gelas plastik ditutup menggunakan kain. Larva diberi pakan daun jagung yang sudah dicuci dan pergantian pemberian pakan dilakukan setiap tiga hari. Ketika mencapai instar ke-3 pakan diberikan setiap hari. Larva yang sudah menjadi pupa dipindahkan ke stoples $5 \mathrm{~L}$ dengan diamaeter 5 $\mathrm{cm}$ dan tinggi $15 \mathrm{~cm}$ yang dijaga kelembapannya. Setelah imago keluar dari pupa, pakan diberikan dalam bentuk larutan madu (air:madu), yakni 2:1. Kapas yang ditetesi larutan madu digantung di dalam stoples. Di bagian sisi bawah stoples diberi kertas minyak sebagai tempat imago meletakkan telurnya. Pakan madu harus tersedia setiap hari. Pengamatan ada tidaknya telur dilakukan setiap hari pada permukaan kertas minyak. Kertas minyak yang ada telurnya diambil dan disimpan dalam wadah plastik untuk pengamatan lanjut pemberian perlakuan pakan bagi larva yang baru menetas.

\section{Pengaruh Pakan dalam Kelangsungan Hidup Spodoptera frugiperda}

Larva $S$. frugiperda digunakan sebagai bahan dalam penelitian ini. Tiga macam pakan diberikan kepada larva sebagai perlakuan dan diulang tiga kali. Pakan yang diuji ialah daun kangkung, daun bawang, dan daun jagung sebagai kontrol. Untuk mengamati pertumbuhan dan perkembangan telur-larva (instar 1- 6)-pupa-imago-telur $S . \quad$ frugiperda dalam menyelesaikan siklus hidup digunakan pertumbuhan dalam wadah yang berbeda seperti akan dijelaskan berikut ini.

\section{Pertumbuhan dan Perkembangan S. frugiperda}

Larva instar 1 diukur panjang dan diameter kepalanya sebelum mendapat perlakuan. Sebanyak 10 larva instar 1 dimasukkan ke dalam gelas plastik berukuran $400 \mathrm{ml}$. Pakan daun yang diberikan kepada larva diberikan secara utuh, tidak dipotong-potong terlebih dahulu dan dilakukan dua hari sekali. Pengamatan lama stadium larva, panjang dan diameter kepala dilakukan pada perubahan larva menjadi instar 2 dan instar 3. Larva instar 3 dipisahkan ke gelas plastik $400 \mathrm{~mL}$ karena larva ini kanibal. Jadi 10 larva perlakuan dipisahkan menjadi 10 gelas plastik setiap perlakuannya. Larva instar 3 sampai dengan instar 6 diberi $1 \mathrm{~g}$ pakan setiap hari. Larva instar 3 sampai dengan instar 6 juga diukur lama stadium, panjang tubuh, serta diameter kepalanya. Panjang tubuh diukur dengan kertas blok millimeter dan diameter kepala jangka sorong digital.

Larva yang sudah memasuki instar 6 dipelihara sampai menjadi pupa, kurang lebih selama 4-7 hari. Selanjutnya pupa dipindahkan ke dalam toples $5 \mathrm{~L}$, pupa yang berumur tiga hari diukur panjangnya. Pupa akan berubah menjadi imago. Pengamatan dilakukan pada corak sayap untuk menentukan jenis kelamin. Imago jantan sayapnya memiliki corak cokelat hampir pada seluruh sayapnya daripada imago betina. Perbandingan jenis kelamin ini menentukan nisbah seks.

Imago dipelihara untuk menghasilkan telur dengan memberi pakan berupa larutan madu 2:1 yang diteteskan pada kapas dan digantungkan di dalam stoples. Di bagian bawahnya dilengkapi dengan kertas minyak sebagai tempat meletakkan telur. Setiap hari pakan diganti dan dilakukan pengamatan terbentuknya telur di atas kertas minyak. Telur disimpan dalam ruang beku suhu $5^{\circ} \mathrm{C}$ supaya tidak cepat menetas. Setelah imago tidak bertelur lagi, jumlah telur dihitung.

Semua data dianalisis dengan uji normalitas Shapiro-Wilk dan data yang tidak normal dilanjutkan dengan uji nonparametrik Kruskal-Wallis.

\section{HASIL DAN PEMBAHASAN}

\section{Panjang Larva dan Diameter Kepala S. frugiperda}

Nilai rata-rata panjang larva $S$. frugiperda instar 1 dan 2 tertinggi yaitu pada pakan daun kangkung, kemudian bawang daun dan terendah yaitu daun jagung (Tabel 1). Rendahnya rerata panjang instar 1 dan 2 pada pakan jagung disebabkan oleh cepat keringnya daun jagung yang sudah dipetik dari tanamannya. Dikarenakan mudah mongering, sehingga kandungann nutrisi yang ada pada pakan tersebut menjadi kurang. Kurangnya kandungan nutrisi pada pakan tersebut menyebabkan rendahnya rerata 
panjang larva instar 1 dan 2 pada pakan daun jagung. Daun jagung yang dipetik adalah daun jagung muda. Hal ini dikarenakana larva instar awal dari S. frugiperda biasanya hidup di daun jagung yang masih muda (Mello da Silva et al. 2016; Sharanabasappa et al. 2018). Menurut Nonci et al. (2019), tempat favorit bagi larva $S$. frugiperda untuk tinggal dan tumbuh adalah pada daun muda tanaman jagung.

Menurut Kalyan et al. (2020), panjang larva instar 2 S. frugiperda yaitu sebesar $0,30-0,40 \mathrm{~cm}$, instar 3 $0,55-0,65 \mathrm{~cm}$, instar $40,90-1,05 \mathrm{~cm}$, instar $51,50-1,80$ $\mathrm{cm}$, dan instar $63,20-3,60 \mathrm{~cm}$. Hasil yang didapatkan mendapatkan hasil yang lebih tinggi dari penelitian yang sudah dilakukan, hal ini dapat dikarenakan selalu tersedianya pakan yang diberikan sehingga larva tidak mengalami defisit makanan. Semakin banyak pakan yang tersedia, maka semakin bertambah juga pertumbuhan dari serangga yang dipelihara tersebut (Cadinu et al. 2020).

Daun kangkung memiliki nilai rata-rata diameter kepala $S$. frugiperda instar 1 tertinggi diibanginkan dua perlakuan lainnya (Tabel 2). Hal ini dikarenakan pada daun kangkung memiliki kandungan nutrisi yang lebih tinggi dibandingkan kedua pakan lainnya. Pakan alami serangga ini di alam berupa daun jagung, akan tetapi ketika diberikan pakan daun jagung di laboratorium hasil yang didapatkan tidak setinggi pada pakan daun kangkung. Hal ini disebabkan karena ketika daun jagung diambil dari tanamannya, daun yang diambil tersebut cepat mengalami kekeringan, sehingga tidak disukai oleh S. frugiperda. Walaupun hasil pada pakan daun kangkung yang didapatkan lebih tinggi dibandingkan penelitian Nonci et al. (2019), akan tetapi pada pakan bawang daun, hasil yang didapatkan lebih rendah dibandingkan penelitian sebelumnya. Rendahnya nilai diameter kepala pada larva yang diberi pakan bawang daun disebabkan karena pada saat memasuki instar 3-6 terdapat larva yang tidak mampu untuk bertahan hidup. Hal ini dikarenakan pada bawang daun memiliki suatu senyawa flavonoid (Utami et al. 2015). Apabila senyawa flavonoid masuk kedalam tubuh larva melalui makanan yang dimakan oleh serangga maka alat pencernaan nya terganggu (Mierziak et al. 2014), sehingga dari hal tersebut dapat mengurangi nafsu makan larva (Hikal et al. 2017). Hal ini juga didukung oleh pendapat Silva et al. (2016) yang menyebutkan bahwa Spodoptera frugiperda yang diberi pakan dengan kandungan flavonoid di dalamnya dapat berpengaruh negatif terhadap pertumbuhannya. Walaupun terdapat larva yang mati pada pakan bawang daun, akan tetapi terdapat larva yang mampu menyelesaikan siklus hidupnya dan bahkan sampai menghasilkan telur. Rasio $S$. frugiperda yang mati pada pakan bawang daun memiliki jumlah yang lebih sedikit dibandingkan jumlah $S$. frugiperda yang dapat bertahan hidup. Jumlah $S$. frugiperda yang mati sebanyak 5 ekor larva dari total 30 larva yang diberi pakan bawang daun. Apabila diteruskan sampai dengan beberapa generasi mendatang dengan telur yang dapat bertahan pada pakan bawang daun, maka dapat dimungkinkan larva yang menetas dari telur tersebut dapat bertahan dan makan pada pakan bawang daun. Hal ini dikarenakan serangga memiliki tingkat adaptasi yang tinggi (Sheikh et al. 2017). Seperti adaptasi Spodoptera exigua yang sekarang menjadi hama utama pada tanaman bawang (Ueno 2015).

Berdasarkan hasil pengukuran panjang larva dan diameter kepala, dapat dilihat bahwa pemberian pakan yang bervariasi memberikan pengaruh terhadap pertumbuhan $S$. frugiperda. Pemberian pakan yang terbaik berdasarkan hasil penelitian terdapat pada pakan daun kangkung, padahal $S$. frugiperda yang digunakan memiliki inang di alam berupa tanaman jagung. Menurut Nonci et al. (2019), kebanyakan perilaku S. frugiperda ketika makan teramati terdapat

Tabel 1 Rata-rata panjang tubuh larva Spodoptera frugiperda instar 1-6 yang diberi tiga jenis pakan daun

\begin{tabular}{cccc}
\hline Stadium larva & & Panjang tubuh $(\mathrm{cm})$ & Daun bawang \\
\cline { 2 - 4 } instar & Daun jagung & Daun kangkung & $0,32 \pm 0,05^{\mathrm{c}}$ \\
\hline 1 & $0,31 \pm 0,03^{\mathrm{a}}$ & $0,43 \pm 0,07^{\mathrm{b}}$ & $0,70 \pm 0,20^{\mathrm{c}}$ \\
3 & $0,66 \pm 0,11^{\mathrm{a}}$ & $1,01 \pm 0,10^{\mathrm{b}}$ & $0,85 \pm 0,84^{\mathrm{c}}$ \\
4 & $1,19 \pm 0,31^{\mathrm{a}}$ & $1,87 \pm 0,24^{\mathrm{b}}$ & $1,11 \pm 1,14^{\mathrm{c}}$ \\
5 & $1,97 \pm 0,33^{\mathrm{a}}$ & $2,07 \pm 0,24^{\mathrm{b}}$ & $1,09 \pm 1,28^{\mathrm{c}}$ \\
6 & $2,31 \pm 0,30^{\mathrm{a}}$ & $2,39 \pm 0,16^{\mathrm{b}}$ & $1,19 \pm 1,39^{\mathrm{c}}$ \\
\hline
\end{tabular}

Keterangan: a,b, dan $\mathrm{c}=$ notasi huruf berbeda tiap baris menunjukkan hasil yang berbeda nyata.

Tabel 2 Nilai rata-rata diameter kepala larva S. frugiperda instar 1-6

\begin{tabular}{cccc}
\hline \multirow{2}{*}{ Stadia } & \multicolumn{3}{c}{ Diameter kepala S. frugiperda (cm) } \\
\cline { 2 - 4 } & $\begin{array}{c}\text { Pakan daun jagung (Rata-rata } \\
\pm \text { SD) }\end{array}$ & $\begin{array}{c}\text { Pakan daun kangkung (Rata-rata } \\
\pm \text { SD) }\end{array}$ & $\begin{array}{c}\text { Pakan bawang daun (Rata-rata } \\
\pm \text { sd) }\end{array}$ \\
\hline Instar 1 & $0,05 \pm 0,00^{\mathrm{a}}$ & $0,09 \pm 0,01^{\mathrm{b}}$ & $0,06 \pm 0,02^{\mathrm{c}}$ \\
Instar 2 & $0,10 \pm 0,01^{\mathrm{a}}$ & $0,10 \pm 0,02^{\mathrm{a}}$ & $0,10 \pm 0,00^{\mathrm{a}}$ \\
Instar 3 & $0,15 \pm 0,05^{\mathrm{a}}$ & $0,19 \pm 0,01^{\mathrm{b}}$ & $0,10 \pm 0,10^{\mathrm{c}}$ \\
Instar 4 & $0,19 \pm 0,02^{\mathrm{a}}$ & $0,20 \pm 0,00^{\mathrm{b}}$ & $0,10 \pm 0,10^{\mathrm{c}}$ \\
Instar 5 & $0,20 \pm 0,00^{\mathrm{a}}$ & $0,20 \pm 0,00^{\mathrm{a}}$ & $0,08 \pm 0,10^{\mathrm{b}}$ \\
Instar 6 & $0,20 \pm 0,00^{\mathrm{a}}$ & $0,20 \pm 0,00^{\mathrm{a}}$ & $0,08 \pm 0,12^{\mathrm{b}}$ \\
\hline
\end{tabular}

Keterangan: a,b, dan c = notasi huruf berbeda tiap baris menunjukkan hasil yang berbeda nyata. 
di daun muda yang masih menggulung. Hal ini juga didukung oleh pernyataan Sharanabasappa et al. (2018) dan CABI (2019), yang menyatakan bahwa larva $S$. frugiperda menyerang titik tumbuh tanaman dan dapat mengakibatkan kegagalan pembentukan pucuk atau daun muda tanaman.

\section{Panjang Pupa Spodoptera frugiperda}

Pengukuran panjang pupa dan berat pupa dilakukan setelah 3 hari mengalami perubahan dari larva ke pupa. Menurut Mardiana et al. (2001), pada awal fase pupa, kulit pupa lunak dan berwarna hijau kekuningan, kemudian akan menjadi keras. Pengukuran panjang dan berat pupa dilakukan setelah 3 hari memasuki fase pupa karena kulit pupa sudah mengeras. Pengukuran panjang pupa dari tiga perlakuan diperoleh nilai rata-rata perlakuan pakan daun jagung sebesar $1,35 \mathrm{~cm}$, daun kangkung $1,40 \mathrm{~cm}$ dan bawang daun $0,58 \mathrm{~cm}$ (Tabel 3 ).

Menurut penelitian dari Kalyan et al. (2020), panjang pupa $S$. frugiperda yaitu sebesar 1,40-1,90 $\mathrm{cm}$. Hasil yang didapatkan sesuai dengan penelitian dari Kalyan et al. (2020). Semakin panjang larva yang didapatkan, maka panjang pupa yang dihasilkan juga akan semakin panjang. Hal ini terkait dengan nutrisi yang tercukupi pada saat larva. Semakin bagus dan cukup nutrisi yang didapatkan pada saat larva, maka tentunya akan menghasilkan pupa yang semakin panjang juga.

\section{Sex Ratio dan Jumlah Telur Spodoptera frugiperda}

Hasil penelitian mengenai perbandingan jumlah sex ratio, perlakuan pemberian pakan daun jagung imago jantan berjumlah 13 dan betina 16, daun kangkung imago jantan berjumlah 11 dan imago betina 14, bawang daun imago jantan berjumlah 7 dan imago

Tabel 3 Nilai rata-rata panjang pupa $S$. frugiperda

\begin{tabular}{lc}
\hline \multicolumn{1}{c}{ Jenis pakan } & Rata-rata panjang pupa \pm \\
SD \\
\hline Daun jagung & $1,35 \pm 0,07^{\mathrm{a}}$ \\
Daun kangkung & $1,40 \pm 0,09^{\mathrm{b}}$ \\
Bawang daun & $0,58 \pm 0,68^{\mathrm{c}}$ \\
\hline Keterangan: a,b,c: notasi huruf berbeda tiap baris \\
menunjukkan hasil yang berbeda nyata.
\end{tabular}

betina 5 (Tabel 4). Dari hasil yang didapatkan, perlakuan yang menghasilkan imago betina paling banyak yaitu pada perlakuan daun jagung, sehingga apabila betina lebih banyak dimungkinkan menghasilkan telur lebih banyak.

Menurut Murua \& Virla (2004), rasio jenis kelamin dari $S$. frugiperda yang diberi pakan jagung menghasilkan rasio jenis kelamin betina lebih banyak, karena $S$. frugiperda sudah memiliki kemampuan untuk beradaptasi dengan pakan daun jagung. Berdasarkan hasil dari penelitian hasilnya sama dengan penelitian Nonci et al. (2019), yaitu rasio jenis kelamin betina dengan pakan daun jagung lebih banyak, sehingga dapat menghasilkan telur lebih banyak. Perhitungan jumlah telur dari tiga perlakuan diperoleh hasil nilai rata-rata jumlah telur pada perlakuan daun jagung yaitu sebesar 2195,33 , daun kangkung 883,67 , dan bawang daun 257 (Tabel 5).

Menurut Nonci et al. (2019) Pada kondisi hangat, seekor betina $S$. frugiperda dapat bertelur 6-10 kelompok telur yang terdiri dari 100-300 butir, menghasilkan 1.500-2.000 telur dalam semasa hidupnya (2-3 minggu). Penelitian ini dilakukan pada rentang suhu $25-29^{\circ} \mathrm{C}$. Berdasarkan hasil penelitian, jumlah telur pada pakan daun jagung hasilnya lebih banyak apabila dibandingkan dengan penelitian Nonci et al. (2019), sedangkan perlakuan pakan daun kangkung dan bawang daun hasilnya lebih rendah apabila dibandingkan dengan penelitian dari Nonci et al. (2019). Semakin banyak betina dihasilkan dari pupa, maka dapat dimungkinkan semakin banyak juga jumlah telur yang akan dihasilkan pada generasi selanjutnya. Tingginya telur pada daun jagung dikarenakan banyaknya kelamin betina yang dihasilkan dari pakan daun jagung. Selain itu, $S$. frugiperda yang ditemukan di Indonesia memiliki inang tanaman jagung, sehingga dapat dimungkinkan larva yang dipelihara sudah teradaptasi dengan baik dengan pemberian pakan daun jagung. Dalam penelitian ini, diketahui bahwa pemberian pakan yang paling bagus dalam proses pertumbuhan $S$. frugiperda yaitu perlakuan pemberian pakan daun kangkung, sedangkan perlakuan yang paling bagus dalam banyaknya betina $S$. frugiperda menghasilkan banyak

\begin{tabular}{|c|c|c|c|c|c|c|}
\hline \multirow{3}{*}{ Ulangan } & \multicolumn{6}{|c|}{ Jumlah sex ratio $S$. frugiperda (ekor) } \\
\hline & \multicolumn{2}{|c|}{ Daun jagung } & \multicolumn{2}{|c|}{ Daun kangkung } & \multicolumn{2}{|c|}{ Bawang daun } \\
\hline & Jantan & Betina & Jantan & Betina & Jantan & Betina \\
\hline P1 & 4 & 6 & 4 & 4 & 3 & 2 \\
\hline $\mathrm{P} 2$ & 5 & 5 & 3 & 5 & 3 & 1 \\
\hline P3 & 4 & 5 & 4 & 5 & 1 & 2 \\
\hline Total & 13 & 16 & 11 & 14 & 7 & 5 \\
\hline
\end{tabular}

Tabel 5 Nilai rata-rata jumlah telur $S$. frugiperda

\begin{tabular}{ccc}
\hline & Jumlah telur betina S. Frugiperda & \\
\hline Pakan daun jagung (Rata-rata \pm & Pakan daun kangkung (Rata-rata \pm & Pakan bawang daun(Rata-rata \pm \\
SD) & SD) & $257,00 \pm 445,137^{c}$ \\
\hline $2195,33 \pm 946,857^{\text {a }}$ & $883,67 \pm 632,155^{\mathrm{b}}$ & 257
\end{tabular}

Keterangan: $a, b$, dan $c=$ notasi huruf berbeda tiap kolom menunjukkan hasil yang berbeda nyata. 
telur yaitu pada perlakuan pemberian pakan daun jagung.

\section{KESIMPULAN}

Rata-rata panjang tubuh $S$. frugiperda tertinggi didapatkan pada pakan daun kangkung dan terendah daun jagung. Nilai rata-rata diameter kepala tertinggi didapatkan pada perlakuan pakan daun kangkung, sedangkan terkecil pada pakan bawang daun. Ratarata panjang pupa $S$. frugiperda yang paling panjang yaitu daun kangkung dan yang paling pendek bawang daun. Rata-rata jumlah telur yang dihasilkan pada daun jagung sebanyak 2195 butir, daun kangkung 883 butir dan bawang daun 257 butir. Perbandingan sex ratio (jantan : betina) pakan daun jagung $13: 16$, daun kangkung $11: 14$, dan bawang daun $7: 5$.

\section{DAFTAR PUSTAKA}

Barros E, Torres JB, Ruberson JR, Oliveira MD. 2010. Development of Spodoptera frugiperda on different host and damage to reproductive structures in Cotton. Entomologia Experimentalist et Applicata. 137: 237-245. https://doi.org/10.1111/j.15707458.2010.01058.x

Cadinu LA, Barra P, Torre F, Delogu F, Madau FA. 2020. Insect rearing: Potential, challenges, and circularity. Sustainability. 12(4567): 1-23. https:// doi.org/10.3390/su12114567

CABI (Centro International de Agriculturs Tropical). 2019. Spodoptera frugiperda (Fall Armyworm). [internet]. [Diakses pada tanggal: 17 September 2019]. Tersedia pada: https://www.cabi.org/ ISC/fallarmyworm.

Hikal WM, Baeshen RS, Said Al-Ahl HAH. 2017. Botanical insecticide as simple extractives for pest control. Cogent Biology. 3: 1-16. https://doi.org/ 10.1080/23312025.2017.1404274

Kalyan D, Mahlan MK, Babu SR, Kalyan RK, Swathi P. 2020. Biological parameters of Spodoptera frugiperda (J.E. Smith) under laboratory conditions. International Journal of Current Microbiology and Applied Sciences. 9(5): 2972-2979. https://doi.org/ 10.20546/ijcmas.2020.905.340

Kementan. 2017. Pengendalian Hama Ulat Bawang (Spodoptera exigua) pada Bawang Merah. Lembang (ID): Badan Penelitian dan Pengembangan Pertanian.

Kianmatee S, Ranamukhaarachchi SL. 2007. Pest repellent plants for management of insect pests of chinese kale, Brassica oleracea L. International Journal of Agriculture \& Biology. 9(1): 64-67.

Maharani Y, Dewi VK, Puspasari LT, Rizkie L, Hidayat
Y, Dono D. 2019. Cases of Fall Army Worm Spodoptera frugiperda J. E. Smith (Lepidoptera: Noctuidae) attack on maize in Bandung, Garut, and Sumedang District, West Java. Jurnal Cropsaver. 2(1): 38-46. https://doi.org/10.24198/cropsaver. v2i1.23013

Mardiana A, Atmowidi T, Amir M. 2001. Morfologi siklus hidup kupu raja Troides helena Linnaeus (Lepidoptera: Papilionidae) yang dipelihara dalam penangkaran. Prosiding Seminar Nasional entomologi dalam Perubahan Lingkungan dan Sosial. Perhimpunan Entomologi Indonesia.

Marsadi D, Supartha IW, Sunari AAAAS. 2017. Invasi dan tingkat serangan ulat bawang (Spodoptera exigua Hubner) pada dua kultivar tanaman bawang merah di Desa Songan, Kecamatan Kintamani, Kabupaten Bangli. E-Jurnal Agroteknologi Tropika. 6(4): 360-369.

Mello da Silva D, Bueno AF, Andrade K, Stecca CS, Neves PMOJ, Neves de Oliveira MC. 2016. Biology and nutrition of Spodoptera frugiperda (Lepidoptera: Noctuidae) fed on different food sources. Scientia Agricola. 74(1): 18-31. https://doi.org/ 10.1590/1678-992x-2015-0160

Mierziak J, Kostyn K, Kulma A. 2014. Flavonoids as important molecules of plant interactions with the environment. Molecules. 19: 16240-16265. https:// doi.org/10.3390/molecules 191016240

Moekasan TK, Setiawati W, Hasan F, Runa R, Somantri A. 2013. Penetapan ambang pengendalian Spodoptera exigua pada tanaman bawang merah menggunakan feromonoid seks. Jurnal Hortikultura. 23(1): 80-90. https:// doi.org/10.21082/jhort.v23n1.2013.p80-90

Murua G, Virla E. 2004. Population parameters of Spodoptera frugiperda (Smith) (Lep: Noctuidae) fed on corn and two predominant grasess in Tucuman (Argentina). Acta Zoologica Mexicana. 20(1): 199-210.

Nonci N, Kalqutny H, Mirsam S, Muis $\mathrm{H}$, Azrai A, Aqil M. 2019. Pengenalan Fall Armyworm (Spodoptera Frugiperda J.E. Smith) Hama Baru Pada Tanaman Jagung Di Indonesia. Maros (ID): Balai Penelitian Tanaman Serealia.

Razak TA, Santhakumar T, Mageswari K, Santhi S. 2014. Studies on efficacy of certain neem products against Spodoptera litura (Fab.). Journal of Biopesticides. 7: 160-163.

Sharanabasappa, Kalleshwaraswamy CM, Maruthi MS, Pavithra HB. 2018. Biology of invasive fall army worm Spodoptera frugiperda (J.E. Smith) (Lepidoptera: Noctuidae) on maize. Indian Journal of Entomology. 80(3): 540-543. https:// doi.org/10.5958/0974-8172.2018.00238.9

Sheikh AA, Rehman NZ, Kumar R. 2017. Diverse 
adaptation in insects: A review. Journal of Entomology and Zoology Studies. 5(2): 343-350.

Silva TRFB, de Sousa Almeida AC, de Lima Moura T, da Silva AR, de Sousa Freitas S, Jesus FG. 2016. Effect of the flavonoid rutin on the biology of Spodoptera frugiperda (Lepidoptera: Noctuidae). Acta Scientiarum. 38(2): 165-170. https:// doi.org/10.4025/actasciagron.v38i2.27956

Ueno T. 2015. Beet armyworm Spodoptera exigua
(Lepidoptera: Noctuidae): A major pest of welsh onion in Vietnam. Journal of Agriculture and Environmental Sciences. 4(2): 181-185. https:// doi.org/10.15640/jaes.v4n2a21

Utami S, Mulqie L, Fitrianingsih PS. 2015. Uji aktivitas ekstrak etanol bawang daun (Allium fistulosum L.) sebagai antihiperkolesterolemia terhadap mencit Swiss Webster jantan. Prosiding Penelitian SPeSIA Unisba. 2460-6472: 568-73. 